\title{
保加利亞人民共和國生物學 和醫學底成就
}

\author{
A. И. 哈德若洛夫
}

12 月底, 在保加利亞有一重大的科學事件. 1952 年 12 月 $25-29$ 日, 保加利亞科學院生 物學和醫學部舉行了科 學 會 議。會 議哑取並討 論了兩個大的報告和 50 個關於植物截培、畜牧 業、微生物學、生理學、形態學、生物化學和醫 學方面的科學報道。

會满明確地指出了, 保加利亞科學院由於仿 做蘇聯科學院的範例, 遂於近年來獲得了巨大的 成就。在蘇聯所進行的關於晢學、生物學、生理 殺、細胞學、語言學和政治經沜學方面的討論, 不僅過去給予和繼續給予保加利亞科 學的思想 上、方法論上和科學組織上的改建以很大的影 響, 而且確定了我國科學研究工作的基本問題和 題目。在報告和科學報道中所研討的許多問題, 都是第農業和怒學的直接需要所指定的。

在達斯卡洛夫院士的報告“ 1949 年保加利亞 科學院生物學會議後㖘業生物學底狀况” 中, 談 到了關於以米丘林學說笏基礎的生物學和農業生 物學的科學組織、研究和筫践的改建方面底措 施。

保加利亞人民步和國底植物栽培、土壤、畜

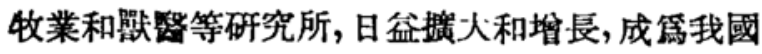
農業生物學的理論和實践底方法論的中心。最近 將来, 這些研究所會成篇獨立的保加利亞科學院 的祳業生物學部, 它將成第創造性地蓮用和研究 藉聯農業生物學的理論和筫践的唯一中心。著名 的蘇聯米丘林工作者們一一齊琴院士、都源、斯 托列托夫、仍沙也夫、巴甫連柯夫和烏阥柯娃俨 等的訪問, 對於農業生物學的蓮用有了特殊的意 珴。他們給予保加利亞濃業生物學的發展以有决 定意義的趣助。
在我們筫践中永公廣泛地應用着米斥林農業 生物學, 例如, 玉蜀㯟、向日政和黑麥的補助授 粉, 棉花的整枝, 耕作, 以及荣四輪作制等。

達斯卡洛夫院士講到了農業生物學的科學的

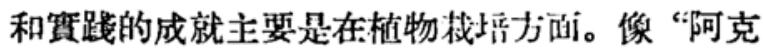
爾曼”小麥品種, 每一捷卡閶（約合一畧牛一 譯者註）曾獲得 635 公厅的收成。赤限潘筫驗研 究所獲得了玉蜀㯟的雜種 “赤爾潘 96 ” 和棉花的 新品種。落䕀、番茄和馬鈴著等新的改良品種巳 經培養出來了, 道些品種忿來意廣泛地被應用到 勞動合作農場上。由於運用蘇聯的裁植榜檬、柑 子的塹倳法, 踓然在素非亞平原的寒冷氣候佟件 下, 終於能在 1952 年初次獲得了成熟的村子。在 畜牧業方面, 則由本地牲畜阔新門塔爾和門塔弗

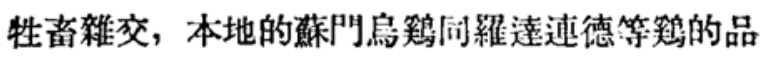
種雜交, 猚得了良好的成果。

第二倜主重報告是 M. 波波夫院士作的, 他 曾多年研究刺激劑的問题。波波大院士, 在保加

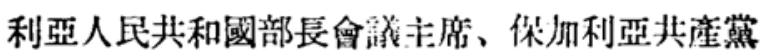
總書記維爾科・契爾文科夫的视白協叻下, 與普 通生物研究所的全體人員一起, 並藉地方科學工

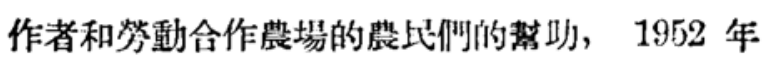

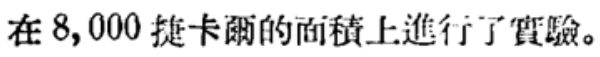

以波波夫院士所選摆的和造成的一定浱度的 有機的和無機的溶液, 正確地规定時間来庭理種

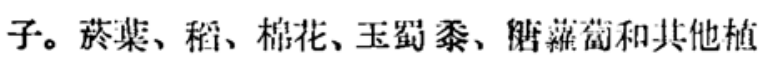
物種子用這種方法處理透的, 它們的㛁均收成,

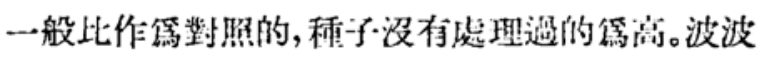
夫院士指出, 種子用溶液處理過的, 得到了較高 的收檴: 稻增到 $18.5 \%$, 樎花 $12.2 \%$, 馬鈴薯 $12 \%$,小麥 $18 \%$, 黑麥 $21.1 \%$, 大麥 $11.8 \%$ 。 
1953 年度將在 10 萬捷卡爾的面積上進行各種植 物的賽驗。

然而在生理學和生物學方面的刺激過程的機 構還研究得不够充分, 這一點在會議上已閶 明 了, 正像保加利亞科學院院長巴甫洛夫院士在閌 幕詞中强調指出的那樣: 在融會主義農 業 焂 作 下, 種子的特殊處理將依米丘林的植物裁培的綜 合方法來進行。

在會議上所宣読過的科學報道, 大部分都是 和生產有直接聯系的。科學院通訊院士 $\Gamma$. 格 奧 爾吉棐娃獲得了馬鈴薯的種間雗 種。通 訊 院士 A. 波波夫作了關於初生期小麥春化作用的貿 驗 結果的報告。老科學工作者 几. 伊里耶夫報導了 棉花的雜種優勢許多有趣的研究, 並且由於某些 雜交, 他獲得了純織維較之原來品種增加 23-51 $\%$ 的收成。

H. 斯托揚諾夫院士在其關於多布鲁德熱的 樹林和灌木鋠的報告中, 講到了利用它們去創造 防護林帶的問題。

B. 馬爾柯夫和 A. 托施柯夫兩院士, 在微生 物學方面, 報道了關於以實行胆石醇溶液的方 法。來減低隇革蘭菌素 (C) 抗生素的毒性的可 能。C. 安果夫院士和通訊院士 K. 奇洛夫作了關 於昆斯蘭疼疾的研究報告。

д. 奥拉霍瓦次阔述了保加利亞科學院整學研
究所的發展, 並詳細談到試驗䂑學研究所的任 務。巴甫洛夫條件反射和神經活㔚類型研究室已 經組成。在研究所內, 除生理學組外, 將組成菻 物學組和生理化舉組。形態學組已成篇獨立的研 究所。

在形態學方面, 巴索夫院士作了關於他已從 事研究三十年的 “由細胞原生質的遖接分裂形成

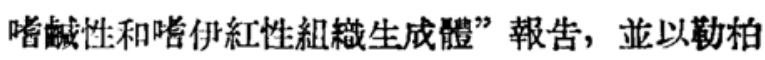
辛斯卡妨學說的精神說明了通一過程。哈德渃洛 夫院士等集體報道了閶於卵黄的組織化學和物理 化學的研究。

年梙的利學工作者P. 察涅夫举報了桐 經 系 統再生的許多有趣的研究。

從祭學和衛生方面的報告中, 可以指出來的 是 A. 康斯坦丁諾夫關於蝶焦對季米特洛夫城媒 磚工廠工人們的影響的研究, 通偣院士奇洛夫和 B.符拉季米羅夫用心挐描記等方法反映情楮對於 心葳的影響的研究。

保加利亞科學院院長 T. 巴甫洛夫院士 結 會議結果時, 着重指出了深刻研究和正確迺用世 界上最進步的科學一一蘇聯科學的經驗的巨大意 義, 因第蘇聯科學是第爭取和平和社會主義而閏 争的全世界真正的、進步的科學家們的旗幟。

$$
\text { 〔本刊特稿予挍䀧〕 }
$$

\section{[上接 34 頁]}

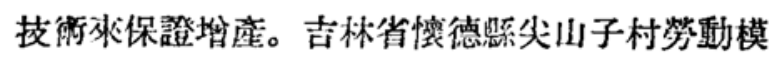
範王文榮要我們解橴第、磷、鉡和作物生長的關 係; 遼西省北欲䝮焱功模範篮會賢要我們講秋翻 的土壤學原理, 要我們講肥料的配合方法。有位

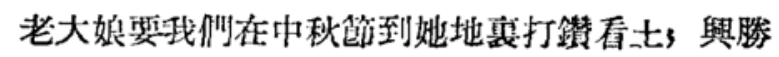

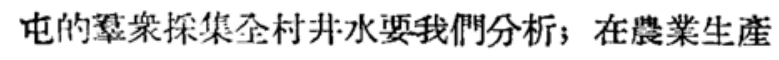
互助組的座談會上, 全組男女老幼都参加, 亚且
遺有別組的組員臨時要求寥加; 在臨離北鎮縣興

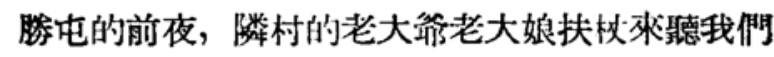
的報告。逜些事䁈永遠刻在我們的心裹, 農民伸

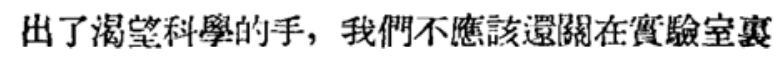

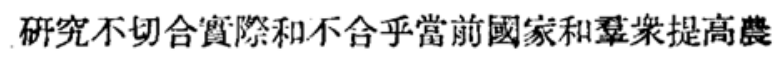
業生產迫切需要的問題, 雇當深入筫践, 把科學 和生產緊密的接合起來。 